\title{
If Spring Should Come
}

If spring should come my hands will turn

To things like dusters, mops and brooms,

Though all the while my heart may be

In pasture spread with Crocus blooms.

The mauve and purple flower cups, the sages' silvery green

Make sodden fields sweet April's own

Where winter's snows have been.

-Mary H. Keyte, Pollockville, Alta.

\section{WINTER'S GOLD}

\section{By ELIZABETH CRUICKSHANK, Regina}

If winter is just a time for memories, enjoy the living present: Join a Bird Group!

When George Watt, with great vision, planned our Parliament Buildings' grounds he could not have foreseen that one day an enthusiastic group of bird-watchers would have named certain sections Redpoll Row, Nuthatch Drive, Kinglet Corner, Chicadee Place and Predator Hill.

As the flocks of Redpolls and Kinglets dwindled we began to hope that we would fail to find the Pigeon Hawk or Northern Shrike on their tall tree watch tower.

The area covered on Saturday afternoons was small but then did not White, Burroughs and Thoreau find their treasure at their door? Humble followers, we.

One day, near Fred Bard's Sanctuary, we waited in the car while the others scouted for water fowl. A heavy fog hung over the marsh, "all the air a solemn stillness holds" save for the reeds and weeds rustling, brittle in their winter dryness. The prairie, now a blurred etching, became fused with sky, the birds' world, our world, at one with the Infinite. Then a little twitter and a small flock of Snow Buntings settled nearby, with a few Redpolls, to bring us back to reality.

Every trip is an adventure somehow, sometime we shall touch the superlative. But it will provide no greater thrill than the sight of two Red-breasted Nuthatches, in bitter cold, clinging, feathers fluffed, to the tree trunk near us; and a Robin alone cn the tree top adding its crimson to the gold of the sunset.
We have our gilded memories to enjoy too. At November's end exploring the depths of the valley ravine we know so well we walked in unforgettable beauty. W a ter gurgled over a fallen log. A stump, arch-shaped, formed a doorway to an emerald fairy-glen. Mosses and lichens gleamed green and amber amid intricate silver traceries with tangerine and iris and ruby glow, a mosaic to conjure up if ever the day may be lonely.

The same ravine, near Christmas, was a plastic-sheathed world. Icicles hung from every low branch jewels that tinkled, and tinkled until we felt like St. Joan, that we were hearing the bells after they had stopped ringing.

A whirring of wings and a family of six bush partridge flew up over our heads. Then Judy and I held cur breath for more beauty to pass by as three young deer, their tails like white flags flying, leapt out before us and with such grace made the next tree shelter. Nancy, that night, disappointed at missing the sight, sleepily concluded that Santa's little reindeer were hiding in Judy's valley.

Shortage of time makes the moments of every nature ramble memorable. With the best of companions we know that "we are weaving in the web of life a bright and golden filling."

Soon the silence of winter will break when "Everything must flower or sing, who hears the bugle-call of Spring."

But this winter has given us so much to record. 